\title{
Integration of Programmed Instruction into Mathematics and Science Teaching: A Panacea to Students Dwindling Interest in Mathematics and Science in Nigerian Schools
}

\author{
Omoniyi Israel Oginni $^{{ }^{*}}$, Olabode Thomas Owolabi ${ }^{1}$ \\ Department of Science Education, Faculty of Education, Ekiti State University, Ado-Ekiti, Nigeria \\ *E-mail: omoniyioginni@yahoo.com, otowolabi@yahoo.co.uk
}

This study examined Programmed Instruction (PI) a panacea to students' dwindling interest in mathematics. Descriptive research of survey design was adopted for the study. A questionnaire was designed to collect data from a sample of seven hundred and fifty (750) respondents which include 700 Students and 50 Teachers from Public and Private Secondary Schools in Ado-Ekiti Local Government Area of Ekiti State in Nigeria. The study revealed that usage of programmed instruction beef up curiosity in mathematics students and resulted to greater retention and mastery of subject matter. Also, the study revealed that lack of trained personnel to help guide students in the use of programmed books, scarcity of programmed books in the society, high cost of procuring programmed books and machine and lack of necessary infrastructural facilities have been the factors militating against the implementation of programmed instruction in schools. Based on the findings, it was recommended that curriculum experts should develop various using the programmed instruction approach. Government should release fund for the development of programmed books and school authority should encourage their teachers to attend seminars and workshops, were they could gain knowledge of how to implement programmed instruction and other pedagogical skills that will enhance the teaching and learning of mathematics. Also, there should be provision of necessary infrastructural facilities in schools for easy implementation of programmed instruction.

The process of learning mathematics varies from one learner to the other as a result of individual, physical and biological differences in them. To some students, mathematics can be very imposing, since it requires a lot of effort from them. Consequently, these categories of students need a lot of motivation to cope with the subject. It is therefore beneficial if mathematics educators can produce instructional strategies that are interesting and stimulating (Tolhurst, 1995).

Over the years, several instructional strategies have been employed by various teachers in the teaching of science and mathematics. Some of these instructional strategies include lecture method, inquiry method, class teaching, project method etc. Though, these strategies cannot be out rightly unfitting for teaching mathematics, some of these instructional strategies are teacher-centred, which do not cater for individual differences in the learners. Despite all the students in the class are taught the same thing at the same rate without minding the fact that students assimilate at different rates and some of them are time consuming. Also, some these instructional strategies give teachers more work to do, thus rendering the teachers inefficient in some area and some make it very difficult to identify weak students in a class (Seweje \& Jegede, 2005; Ogundola, 2010).

As a result, students viewed mathematics as a difficult subject. The role of students is to receive mathematics knowledge and to be able to apply correctly when the need arises in sciences and other related subjects. While that of teachers is to transmit this knowledge and ascertain that students acquired it. (Borasi, 1990). In the past four decades mathematics learning has aroused considerable interest at all level of education. Several alternatives pedagogy has been promulgated since the days of Aristotle. Students plan their own time schedule, usually by receiving and completing assignment and thereby raise their interest and their achievement in a subsequent test performance (Kurbanoglu, esenligil, \& Sozbilir, 2006).

ISSN $2165-8714$

Copyright (C) 2012 EU-JER

http://www.eu-jer.com DOI: 10.12973/eu-jer.1.3.199 
Programmed Instruction is one of student-centred aspect of teaching. Programmed Instruction was among the first in the history for instructional developments, analytical processes and instructional design. The programmed instruction employs the use of printed self-instruction to all school subject areas. Later, as the technology developed, other media, such as radio, television, video and computer came into use. Computer-assisted instruction, which both tests students' abilities and mark their progress supplement classroom activity and help students to develop ideas or skills independently.

Programmed Instruction was introduced in 1954 by B.F Skinner of Harvard (Skinner, 1954). Programmed Instruction has been found to be very effective because of active students' participation, small steps, immediate feedback and reinforcement. All students work through the same sequence (Anderson and Fretzin, 2004). According to Chen (2006), programmed Instruction is desirable in many instructional setting because it provides immediate knowledge and feedback, enhanced individualized learning in mathematics instruction. Lee (2004) defined programmed instruction as an instructional strategy in which the learner is presented in many small learning frame or pieces of information in a logical sequence. The learner under the system of instruction is expected to respond to items presented in a logical sequence. The learner's positive response is immediately reinforced and is presented to the next framed of work.

Programmed instruction consists of self-teaching with the aid of a specialized textbooks or teaching machines that are structured logically and empirically developed in a sequential manner. Programmed instruction may be presented by the teachers as well. Interest is a condition of wanting to know or learn about something. Obodo (1991) defined interest as the feeling of intentness, concern and curiosity about an object. Interest is important in the teaching process and in the absorption of the students in their learning. Interest may be conceptualized as a variable which affects both motivational and cognitive activity (Orlando, 1997). Interest played an important role in mathematics education. Mathematics has been a highly respected discipline in school for centuries and its high status makes students' success in mathematics very important. Students' interest has become a point of focus of researchers in mathematics education and it has been pointed out that students' attitude and beliefs about mathematics are strongly related to their learning outcomes and success in mathematics (Kirsti, 2005)

It is not a hidden fact that students have very low interest in mathematics at all levels of learning. However ,those students with mathematics disability perform poorly in science subject like Physics and Chemistry. Some of the causes of students' low interest in mathematics as identified by Obodo (2001) includes Teacher's factor, Lack of Mathematics Laboratory, Poor Student Background and Cultural Bearing of the content. Gilbert (1986) expressed that family influence and SocialEconomic status of parents contributed to the low interest of students in mathematics. Also, the emergence of gender difference has been identified by Fennema (2000) as a factor causing low interest in mathematics. There is no doubt that programmed instruction has many applications both in the classroom setting and in other settings where the efficient acquisition of behaviours, facts and skills are of primary concern. The need to apply it in mathematics teaching is very imperative in sustaining interest of students in mathematics. Analysing the problems and challenges of programmed instruction, it has been discovered that there are some factors militating against the adopting of programmed instruction in schools. These factors include cost, lack of trained personnel, school factors, power constraint and lack of consistency.

\section{Types of Programmed Instruction}

Programmed instruction can be designed to present information to learners in either Linear or branched fashion.

(C) 2012, European Journal of Educational Research, 1(3), 199-209 


\section{Linear Programs}

These allow students to advance through the instructional process in a particular order as they provide correct answers. Students are provided with specific pieces of information in a series of frames and asked to recall or apply this information during frequent tests of comprehension. Frames here imply small unit of instruction presented to students at a time. Each frame contains small information and a statement with a blank that the students fill in. The students then uncover the correct answer before going to the next frame (Anderson \& Fretzin, 2004)

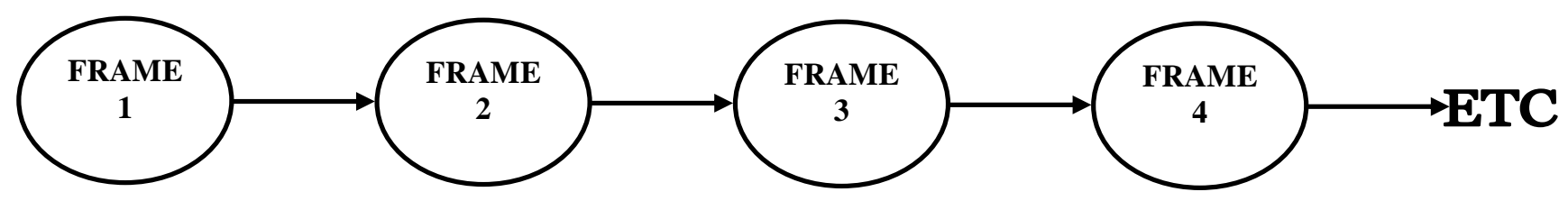

In linear programming all students complete the same sequence of frames. If a student provides a correct response, the student moves to the next frame. Linear programs make no accommodation for errors by the student because it is assumed that a student will provide correct responses for nearly every question. (Lockee, Moore \& Burton, 2004).

\section{Branched Programs}

These are also called intrinsic programs. These offer students a variety of pats through a curriculum. This technique provides the students with a piece of information, presents a situation requiring a multiple choice or recognition response, and on the basis of that choice instructs the students to proceed to another frame, where he or she learns if the choice was correct or not. A student who responded incorrectly will either be returned to the original frame, or routed through a sub-program designed to remedy the deficiency indicated by the wrong choice. A student who selects correctly advances to the next frame in the program. This process is repeated at each step throughout the program, and a student may be exposed to different materials depending on errors made. (McDonald, Yanchar, \& Osguthorpe, 2004).

According to Joehnig and Miller (2007) branched programs involve the format below:

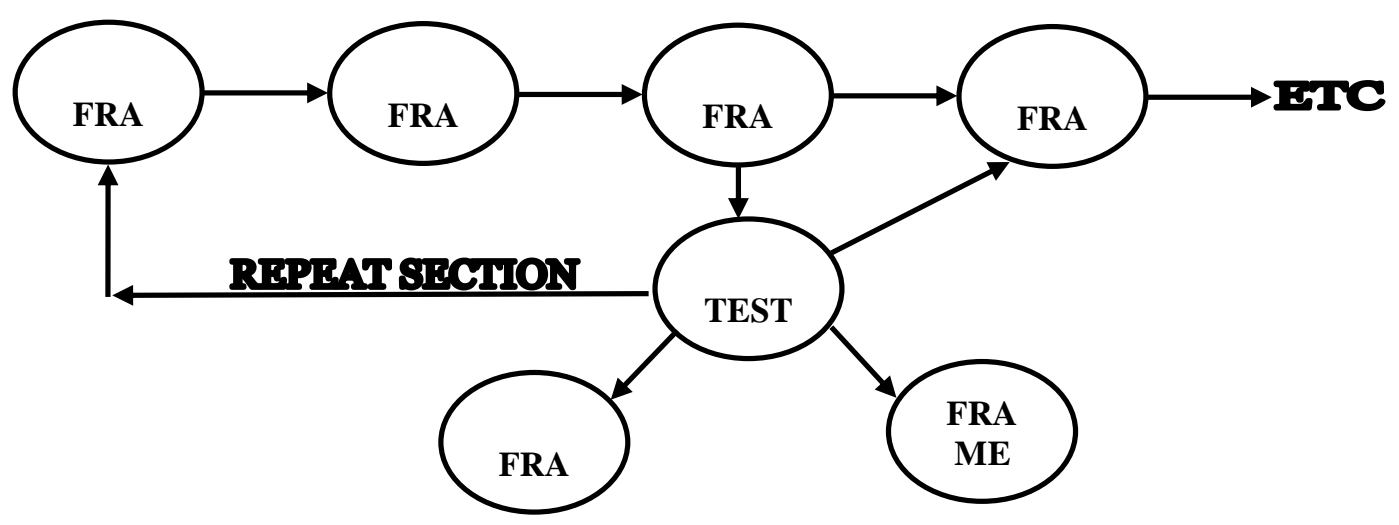

Branched programming is similar to linear programming except that it is more complicated because it attempts to diagnose the learner's response. Also, branching is used with the idea that slow learners can be presented with additional information if they cannot respond will enough to a sequence 
of frames and that more advanced students can be exposed to more challenging materials. (Highbeam Encyclopeadia, 2006).

\section{Statement of the Problem}

Despite the fact that interest of students play a vital role in the learning of mathematics and it is strongly related to students' learning outcomes, it has been observed that, much have not been done in most school in addressing this issue. Outdated teaching practices and lack of basic content knowledge have resulted into poor performance of students in mathematics. The poor standards have also been exacerbated by a large number of unqualified teachers in the area of programmed instruction. These combinations of factors have made students see mathematics class boring, meaningless and uninvolving. Also, the inability of the school to provide good mathematics laboratory coupled with students' poor mathematics background have resulted into more decline of students' interests in mathematics.

\section{Purpose of the Study}

The study tends to examine how the use of programmed instruction would help to boost the interest of students in mathematics and science subjects, and to re-shaping students' attitude towards programmed instruction. More so, the study would help to ascertain the role of the school in adopting programmed instruction and find out the prospect for implementation of programmed instruction. It will also help to analyse the factors, which help to overcome problems of implementing programmed instruction.

\section{Research Questions}

For the purpose of this study, the following questions are raised

1. What are the school related factors militating against the implementation of Programmed Instruction?

2. What are the effects of Gender difference to the use of Programmed Instruction in learning mathematics?

3. Does the use of Programmed Instruction create curiosity in the students?

4. Does the use of Programmed Instruction result in greater retention and mastery of subject matter?

5. What are the importances of Programmed Instruction to learning mathematics?

\section{Research Hypotheses}

The following hypotheses were formulated based on the research questions

1 There is no significant relationship between school factors and programmed instruction

2 There is no significant relationship between gender differences and programmed instruction

3 There is no significant relationship between students curiosity and programmed instruction

4 There is no significant relationship between students; retention level and programmed instruction

5 There is no significant relationship between mastery of the subject matter and programmed instruction 


\section{Significance of the Study}

The study would reveal the latent problems of adopting programmed instruction in school, with the view to proffer solution to those problems. It will help sensitize the school on the use of programmed instruction and its extension to other area of study. It would be beneficial to curriculum experts, in that it would help them to construct curriculum that enhances intellectual substance with programmed instructions in view. Also, it would help to sensitize publishers and professional bodies in the development of books and course materials in line with the programmed instruction format

\section{Methodology}

This study adopted the survey type of descriptive research. The design is considered appropriate for this study because it does not involve manipulation of variables. The population for the study comprises of all Secondary School Students in Ekiti State Nigeria. A total number of 700 Students and 50 Teachers were sampled using simple random sampling techniques. The Research Instrument used in carrying out this study is a Structured Questionnaire on Programmed Instruction (SQPI); targeted to elicit necessary information from the selected subjects. To ensure the validity of the instrument, the questionnaire was presented to the experts' lecturer in mathematics education and science education for assessment and necessary modification in order to ensure the face and content validity of the instrument. The reliability of the instrument was ascertained by using split half method of reliability coefficient, which was given to be 0.86 at 0.05 level of significance. The data collected were analysed using Chi-square and t-test statistical procedure.

\section{Results and Discussion}

1 There is no significant relationship between school factors and programmed instruction.

Table 1. Statistical Analysis on factors militating against the implementation of programmed instruction

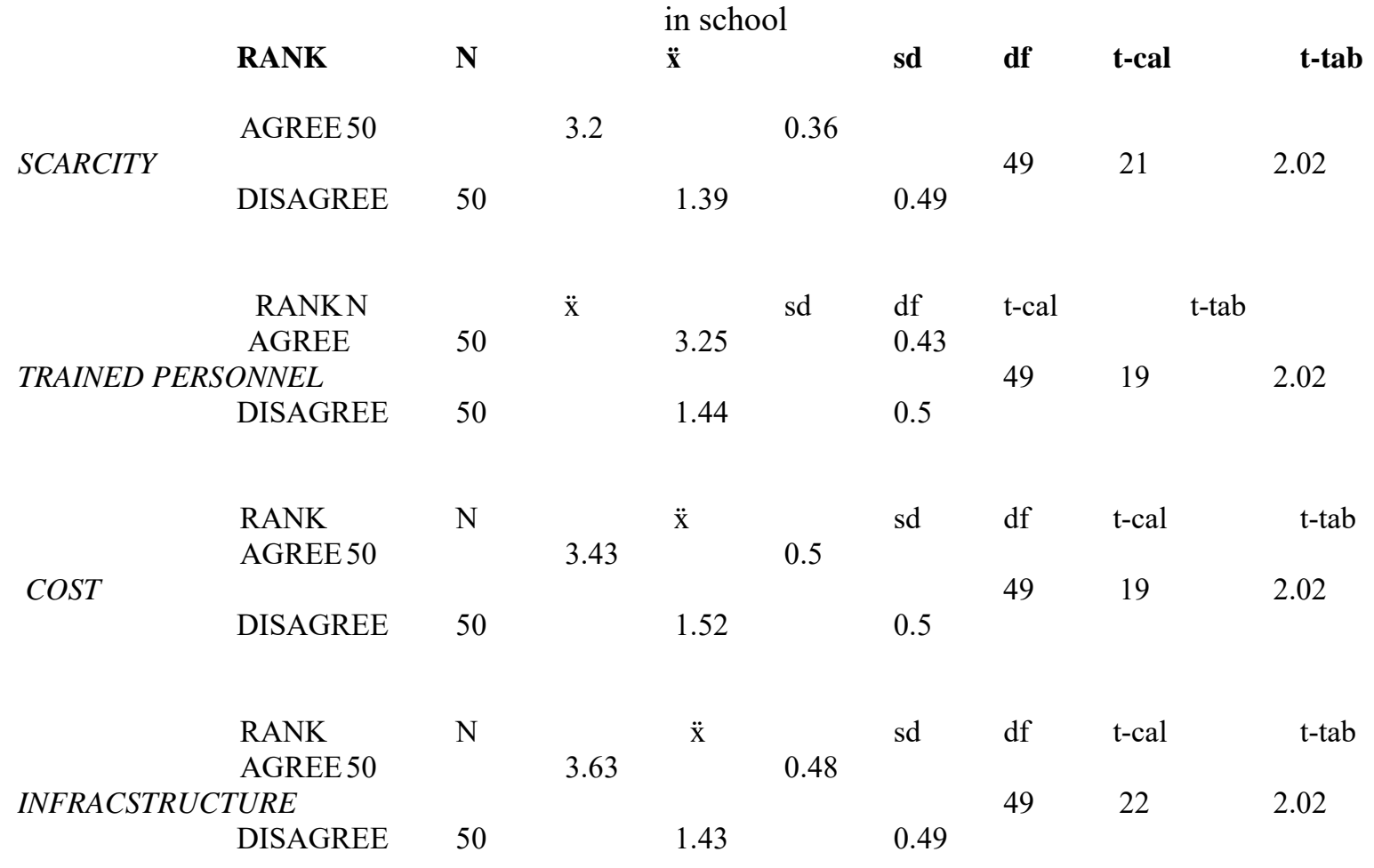


Table 1 shows the means, standard deviation and t-test of factors militating against the implementation of programmed instruction in schools. For scarcity of programmed books, the mean and standard deviation for those who agreed that scarcity of programmed book is a factor affecting implementing programmed instruction in school are 3.152 and 0.359 and for those who disagreed are 1.386 and 0.487 respectively. The t-cal value is 20.7 and while the t-table value is 2.01 . Since the calculated value is higher than the tabulated value, it is concluded that scarcity of programmed books is a school related factor militating against the implementation of programmed instruction. Similar decisions were taken for lack of trained personal, cost of programmed books and lack of infrastructural facilities. Hence, the null hypothesis was rejected.

2 There is no significant relationship between gender differences and programmed instruction

Table 2a. Effect of gender difference in the use of programmed instruction

$\begin{array}{llllll} & \text { SA } & \text { A } & \text { D } & \text { SD } & \text { TOTAL } \\ \text { MALE } & 88 & 166 & 66 & 42 & 357 \\ \text { FEMALE } & 69 & 111 & 96 & 67 & 343 \\ \text { TOTAL } & 152 & 277 & 162 & 109 & 700\end{array}$

Table 2b. Contingency table for the expected frequency.

$\begin{array}{lllrrr} & \text { SA } & \text { A } & \text { D } & \text { SD } & \text { TOTAL } \\ \text { MALE } & 78 & 141 & 88 & 56 & 358 \\ \text { FEMALE } & 74 & 136 & 79 & 53 & 342 \\ \text { TOTAL } & 152 & 277 & 162 & 109 & 700\end{array}$

Table 2c. Chi-square calculation table for gender difference

$\begin{array}{llccl}\mathbf{O} & \mathbf{E} & (\mathbf{O}-\mathbf{E}) & (\mathbf{O}-\mathbf{E})^{\mathbf{2}} & (\mathbf{O}-\mathbf{E})^{\mathbf{2}} / \mathbf{E} \\ 88 & 78 & 5 & 25 & 0.33 \\ 186 & 141 & 25 & 625 & 4.44 \\ 66 & 88 & -17 & 289 & 3.49 \\ 42 & 56 & -14 & 196 & 3.5 \\ 69 & 74 & -5 & 25 & 0.34 \\ 111 & 136 & -25 & 625 & 4.6 \\ 96 & 79 & 17 & 289 & 3.66 \\ 67 & 53 & 14 & 196 & 3.7 \\ & & & \square \mathbf{2} & \mathbf{2 4 . 0 6}\end{array}$

$\mathrm{Df}=(\mathrm{r}-1)(\mathrm{c}-1)$

$=(4-1)(2-1)$

$=3$ At $\alpha$ level of 0.05 , the chi-square tabulated value is 7.82

„Since the calculated value is greater than the chi-square $\left(\chi^{2}\right)$ tabulated value, therefore gender difference affects the use of programmed instruction. There is no significant relationship between students curiosity and programmed instruction. 
Table 3. Programmed instruction create curiosity in the students

$\begin{array}{cccccc} & \mathbf{O} & \mathbf{E} & (\mathbf{O}-\mathbf{E}) & (\mathbf{O}-\mathbf{E})^{\mathbf{2}} & (\mathbf{O - E})^{2} / \mathbf{E} \\ \text { SA } & 234 & 175 & 59 & 3481 & 19.9 \\ \text { A } & 305 & 175 & 130 & 16900 & 96.6 \\ \text { D } & 76 & 175 & -99 & 9801 & 56 \\ \text { SD } & 85 & 175 & -90 & 8100 & 46.3 \\ \text { TOTAL } & 700 & 700 & & \square 2 & 218.8 \\ & \text { Df }=\mathrm{n}-1 & & & \\ & =4-1 \\ & =3\end{array}$

At $\alpha$ level of 0.05 , the chi-square tabulated value for $3 \mathrm{df}$ is 7.82 . Since the calculated value is greater than the chi-square $(\chi 2)$ tabulated value, therefore programmed instruction create curiosity in the students. There is no significant relationship between students; retention level and programmed instruction.

Table 4. Programmed Instruction results and retention level.

\begin{tabular}{|c|c|c|c|c|c|}
\hline & 0 & $\mathbf{E}$ & (O-E) & $(\mathrm{O}-\mathrm{E})^{2}$ & $(\mathrm{O}-\mathrm{E})^{2} /$ \\
\hline SA & 242 & 175 & 67 & 4489 & 25.7 \\
\hline A & 280 & 175 & 105 & 11025 & 68 \\
\hline D & 94 & 175 & -81 & 6661 & 37.5 \\
\hline SD & 84 & 175 & -91 & 8281 & 47.3 \\
\hline TOTAL & 700 & 700 & & $\square 2$ & 173.5 \\
\hline & \multicolumn{2}{|c|}{$\begin{aligned} \mathrm{Df} & =\mathrm{n}-1 \\
& =4-1 \\
& =3\end{aligned}$} & & & \\
\hline
\end{tabular}

At $\alpha$ level of 0.05 , the chi-square tabulated value for $3 \mathrm{df}$ is 7.82

Since the calculated value is greater than the chi-square $\left(\chi^{2}\right)$ tabulated value, therefore programmed instruction usage results in greater retention and mastery of subject matter. There is no significant relationship between mastery of the subject matter and programmed instruction.

Table 5. Programmed Instruction results and mastery of subject matter

$\begin{array}{cccccc} & \mathbf{O} & \mathbf{E} & (\mathbf{O}-\mathbf{E}) & (\mathbf{O}-\mathbf{E})^{2} & (\mathbf{O}-\mathbf{E})^{2} / \mathbf{E} \\ \text { SA } & 207 & 175 & 122 & 14884 & 85.051 \\ \text { A } & 219 & 175 & 44 & 1936 & 11.063 \\ \text { D } & 111 & 175 & -64 & 4096 & 23.406 \\ \text { SD } & 73 & 175 & -102 & 10404 & 59.451 \\ \text { TOTAL } & 700 & 700 & & \square 2 & 178.97 \\ & \quad \text { Df }=\mathrm{n}-1 & & & \\ = & 4-1 \\ = & \end{array}$

At $\alpha$ level of 0.05 , the chi-square tabulated value for $3 \mathrm{df}$ is 7.82 . Since the calculated value is greater than the chi-square $\left(\chi^{2}\right)$ tabulated value, therefore programmed instruction has importance in the learning of mathematics. 


\section{Discussion}

The analyzed data brings a lot of insight into the role of programmed instruction in boosting the dwindling interest of students in mathematics. From the result gathered, it was observed that school related factors militate against the implementation of programmed instruction schools. The findings revealed that scarcity of programmed books in the society has not made the implementation of programmed instruction in schools possible. This could be traced to the facts that curriculum experts have not really paid much attention to the efficacy of programmed instruction in learning. Much emphasis have been only on the development of texts in the conventional teaching approach, thus leaving the potential of programmed instruction in teaching process untapped.

The results revealed that where programmed books are scarcely available, personnel to help implement its usage are not readily available. Thus, lack of trained personnel in schools to guide students in the usage of programmed books has also been a factor hindering the adoption of programmed instruction in school. This also depicts the view of Ogundola (2010) as a problem associated with the implementation of individualized learning in Nigeria.

The findings also revealed that costs of procuring programmed books, machine and running programmed machine are exorbitant. This has remained a great factor hindering the implementation of programmed instruction in schools. This could be due to high financing cost involved in the development of programmed books and machine by individual and the non-involvement of governmental agencies in financing the development of programmed books and machine. It also revealed that school does not have adequate infrastructural facilities that would support the easy implementation of programmed instruction. Some of the facilities lacking in schools include ICT and ICT centre, standard generating set for continual supply of power etc. The inability to provide these facilities in schools has rendered the implementation of programmed instruction very difficult.

The result revealed that gender difference affects the use of programmed instruction. This depicts the view of Mckeon and Comber (2003), whose research studies pointed out that female gender expresses lack of confidence in science base subject, which has been lingering for years. The same view was upheld by Aigbomian (2002) that boys perform better than girls in science and technology.

In the same vein, the findings revealed that programmed instruction results in greater retention and mastery of subject matter in students. This view was also upheld by Nowell and Quinn (2001), who reported that the use of programmed instruction resulted in better academic performance in students. It also revealed that programmed instruction create curiosity in learners when exposed to the method. This also depicts the view of Hayes and Robinson (1999).

Lastly, it was revealed from the findings that programmed instruction has importance in mathematics learning. With programmed instruction, learners determine their own pace and progress. This eliminates frustration with themselves, their fellow learners, and the subject matter. Knowledge is cumulative as programmed instruction presents materials in a pyramid format. Furthermore, programmed instruction makes students discover facts themselves. This makes them more responsible for their learning. Programmed Instruction also helps reduce much load on the teachers as they will majorly serve as supervisor in the use of programmed instruction. Students also agreed that, when involved in a work, they have no time to be engage in any act of indiscipline. This implies that with the use of programmed instruction in classroom, discipline will be maintained as students will be actively involved in their work. This also depicts the view of Ogundola (2010). 


\section{References}

Aigbomian, D. O. and Umeoduagu, T. N. (1992). The relationship between students' attitude and their performance in Integrated Science. BENSU. Journal of Education, 3 (2) 93.

Aigbomian, D.O. (2002): Science For All: Implication for the Teacher and National Development: Inaugural Lecture in Ambrose Alli: University, Ekpoma 27th June. Ambik Press

Anderson T. and Fretzin, L., (2004). Programmed instruction, http://lrs.ed.uiuc.edu/students/fretzin/epl1q2programmed.htm, (accessed_on July 2004).

Author W. (1996). Advantages of pattern Based Mathematics Curriculum $\mathrm{http} / /$ www.Aims.edu.org.Documents/pattern/part2.

Borasi, R. (1990). The invisible hand operating on mathematics instruction: Students conceptions and expectations. In T. J. Cooney (Ed.), Teaching and learning mathematics in the 1990s (NCTM Yearbook), pp. 174-182. Reston: NCTM.

B.F. Skinner Foundation, 2002. Brief biography of B.F. Skinner [WWW document]. Retrieved September 9, 2002 from http://www.bfskinner.org/bio.asp

Center for Programmed Instruction (2002). Programmed Instruction Tutorial [WWW document]. Retrieved October 8, 2002 from http://www.centerforpi.com.

Charanchi, A. A. (2001): Catalogue of Generators of Interest In Mathematics: JORIND 9(2) December, 2011. ISSN 1596 - 8308. www.transcampus.org., www.ajol.info/journals/jorind

Chen, I. (2006). An electronic textbook on instructional technology. Retrieved 17:00, July 4, 2006 from http://viking.coe.uh.edu/ ichen/ebook/et-it/cover.htm.

Chin, C. and Brown, D. E. (2000): Learning in Science: A Comparison of Deep and Surface Approaches. Journal of Research in Science Teaching, 37, 109-138.

Colbum, A. (2005). "What Teacher Education Need to Know about Inquiry-based Instruction"http://www.csulb.edu/ acolbum/AETS.htm

Dallos, R. (1991): The effects of anxiety and intelligence on learning from Programmed Instruction. Programmed Learning and Educational Technology, 13(2), 69-76.

Dee, J. (2003). "Classroom--Based Practices: Engineering Education, Vol. 94, No. 1, 87-101

Ellison, John, (2002). Computer-Assisted Instruction/Programmed Instruction [WWW document]. Retrieved October 8, 2002 from http://informatics.buffalo.edu/faculty/ellison/Syllabi/519Complete/formats/programmedinstr/pro gram.html\#unique.

Eshleman, J. W. (1999). Pluses and minuses of programmed instruction. Retrieved 16:30, July 4, 2006, from http://members.aol.com/johneshleman/comment05.html.

Fenemma, E. (2000). Gender and Mathematics. What is known and what I wish was known? A paper presented at the fifth annual forum of the National Institute for Science Education. Wisconsin centre for educational research.

Gilbert, C. (1986). Infuence familiale le coixd'une carrie're non traditionalle chex les files. Lafortune (ed)

Glas, E: (1999). Teaching and Learning with cases: New York Chatham House Publishers

Harden, J. and Whitelegg, E. (1997). Encore? Gender, Science and Technology. Where are they now? Science Education

Newsletter,

135.9

Haury, D. (1993). "Teaching Science through Inquiry" "ERIC/CSMEE Digest, ED359048

Hidi, S. (1990): Interest and its Contribution as a Mental Resource for Learning. Review of Education Research 60(4), 549-571

Hidi, S., \& Renninger, K. A. (2006). The four-phase model of interest development. Educational Psychologist, 41(2), 111-127.

HighBeam Encyclopedia, \& University of Columbia (2006). Programmed Instruction. Retrieved December 9, 2006 from 
Jaehnig, W. and Miller, M.L. (2007). Feedback types in programmed instruction: A systematic review. The Psychological Record, 57, 219-232.

Joyce, B., Weil, M., Calhoun, E. (2000). Models of Teaching, 6th Edition, Allyn \& Bacon.

Kirsti, K. (2005): Structuring Students' Beliefs in Mathematics

Knowlton, J., \& Hawes, E. (1995). Attitude: Helpful predictor of audiovisual usage. AV Communication Review, 10(3), 147-157.

Kurbanoglu, N.I., Taskesenligil, Y., \& Sozbilir, M. (2006). Programmed instruction revisited: a study on teaching stereochemistry. Chemistry Education Research and Practice, 7(1), 13-21.

Lee, V. S. (2004). Teaching and Learning through Inquiry; Sterling, V.A. Stylus Publishing

Leshin, C., Pollock, J., Reigeluth, C. (1992). Instructional Design Strategies and Tactics. New Jersey: Educational Technology Publications.

Lockee, B. B., Moore, D. M., \& Burton, J. K. (2001). Old concerns with new distance education research. Educause Quarterly, 24, 60-62.

Lysaught, J. P., \& Williams, C. M. (1993). A guide to programmed instruction. New York: John Wiley and Sons.

Mckeon, D. and Comber C. (2003). Gender Difference in Science learning and Performance: Journal Science Education : $12-15$

McPhan, G., Morony, W., Pegg, J., Cooksey, R., \& Lynch, T. (2008). Maths? Why Not? (Report): Australian Department of Education, Employment and Workplace Relations (DEEWR).

Morell, P. D. (1999). The effects of computer -assisted instruction and students' achievement in high school biology. School Science and Mathematics, 92(4), 177-181.

McDonald, J.K. Yanchar, S. C., \& Osguthorpe, R.T. (2005). Learning from programmed instruction: Examining implications for modern instructional technology. Educational Technology Research \& Development, 53(2), 84-98.

Nowell, A. M. B. and Quinn, D. W. (2001). Learning from Home while Comparing Abroad: Mathematics achievement in TIMSS and the first in the world Schools. TIMSS Report, $2001 \mathrm{Na}-$ tional Conference at NMC Abuja.

Obodo, G. C. (1996). Gender Difference in the Mathematical Potentials of Fourteen year Old children: Implication for pace Education: Journal of Research in Science and Technology Education

Obodo G.C (2001). The generating student's interest in Mathematics A paper presented at National Conference at NMC Abuja.

Ogundola, I. P. (2010). Design and use of various Instructional Strategies in the Dynamics of Instruction edited by Jegede S. A. \& Popoola A. A.

Orlich, D. C., Harder, R. J., Callahan, R. C., \& Gibson, H. W. (2001). Teaching Strategies: A guide to better instruction. New York, NY: Houghton Mifflin Company.

Phillips S. D. (1984). Contribution and Limitations in the use of computers in counselling training. Counselor Education and Supervision 24 (2), 186-192.

Programmed Instruction, The Columbia Encyclopedia, Sixth Edition. 2001-05. HTML, retrieved 16:22, 16 August 2007 (MEST)

Programmed Instruction (2006). In Wikipedia, The Free Encyclopedia. Retrieved 22:30,July 4, 2006, from http://en.wikipedia.org/wiki/Programmed_instruction.

Seweje, P. O \& Jegede, S. A. (2005). Science Education and Science Teaching Methods. Atlantic Associated Publishers, Lagos.

Skinner, B.F. (2003). The technology of teaching. Cambridge, MA: B.F. Skinner Foundation.

Smith, K. U., \& Smith, M. F. (1996). Cybernetic principles of learning and educational design. New York: Holt, Rinehart \& Winston.

Schiefele, U. (1991). Interest, learning, and motivation. Educational Psychologist, $26(3$ \& 4), 299-323.

(C) 2012, European Journal of Educational Research, 1(3), 199-209 
Tolhurst D (1995). Hypertext, hypermedia, multimedia defined? Educ. Technol., 35: 21-26.

Trautwein, U., Ludtke, O., Köller, O., Marsh, H. W., \& Baumert, J. (2006). Tracking, grading, and student motivation: Using group composition and status to predict self-concept and interest in ninth-grade mathematics. Journal of Educational Psychology, 98(4), 788-806.

Tretter, T., \& Jones M. (2003). Relationship between inquiry-based teaching and physical science standardized test scores, School Science and Mathematics, 103(7), 345-350. 